\title{
Performance Comparison of Solar Assisted and Inverter Air- Conditioning Systems in Malaysia
}

\author{
M. Arkam C. Munaaim ${ }^{1}$, Karam M. Al-Obaidi² ${ }^{2 *}$ and M. Azizul Abd Rahim ${ }^{1}$ \\ ${ }^{1}$ School of Environmental Engineering, Kompleks Pusat Pengajian Jejawi 3, Universiti \\ Malaysia Perlis, 02600, Perlis, Malaysia \\ ${ }^{2}$ Centre for Building, Construction and Tropical Architecture (BuCTA), Faculty of Built \\ Environment, University of Malaya, 50603, Kuala Lumpur, Malaysia \\ *karam_arc@yahoo.com
}

\begin{abstract}
Heating, ventilation, and air-conditioning (HVAC) systems account for approximately 55\% of the total energy consumption in buildings. Different types of cooling technologies that integrate solar thermal energy have been explored because of increasing worldwide energy shortage. Latest air-conditioning systems have achieved improved energy efficiency. The application of solar energy to various types of HVAC systems proved its huge potential for reducing energy usage. However, solar radiation is highly time dependent and fails to meet building demand. In this study, the potential of a 1.5 HP solar assisted air-conditioning system was evaluated by collecting and using real data, including current, voltage, power, and temperature. The application of the solar-assisted and inverter-type air-conditioning systems was compared for evaluating their performances. The study was conducted in the northern region of Malaysia, specifically Kedah, in a room with the same as that of a standard office space. Results showed that the average coefficients of performance of the solar assisted airconditioning system ranged from 3.00 to 4.45 . This range allows for the optimal consumption of electric energy without wastage. Therefore, the solar-assisted air-conditioning system can provide an environmentally friendly alternative to reducing electricity rates.
\end{abstract}

Keywords: HVAC; solar assisted air-conditioning; inverter split; energy efficiency; Malaysia

\section{INTRODUCTION}

Heating, ventilation, and air-conditioning (HVAC) systems are responsible for approximately $55 \%$ of the total energy consumption in buildings (Al-Abidi et al., 2012). HVAC contributed to the reduction of fossil fuel resources and production of greenhouse gases, which are known to cause ozone layer depletion. Studies showed that the total number of air-conditioning units in residential buildings in Malaysia was 493,082 in 1999. This figure increased by $6.7 \%$ (528,792 units) in 2000 and by roughly $42 \%$ (907,670 units) in 2009 (Saidur et al., 2007). Therefore, different types of cooling technologies in combination with solar thermal energy have been explored in recent years because of world energy shortage.

Solar energy is harnessed in airconditioning systems with either photovoltaic (PV) panels or heat-driven absorption systems. The application of solar energy to various types of HVAC systems proved its huge potential for reducing energy usage. However, solar radiation is a highly time-dependent energy resource and it does not always meet the building demand (Munaaim et al., 2014; Al-Obaidi et al., 2017). This problem can be addressed by storing and releasing thermal energy according to building load (Aminuddin and Rao, 2008; Sulaiman, 2005). Therefore, an appropriate control method should be employed by solar assisted HVAC systems to adjust the stored solar thermal energy according to the transient building demand.

Fong et al. (2010) evaluated five types of solar assisted cooling systems in Hong Kong; these systems require an electricity grid and heat sources to support the system when solar energy is insufficient. This conclusion is supported by similar findings obtained by Gupta (2011), who helped condition a house in Phoenix, Arizona after comparing three types of solar air-conditioning systems. Gupta (2011) showed that in addition to costs and technical challenges, another issue that needs to be addressed is the requirement for a large solar collector, which might be larger than a roof when the solar fraction approaches unity. Balaras et al. (2007) confirmed that different results can be obtained under different loading 
and weather conditions by conducting a comparative study of 50 European projects. Fong et al. (2010) highly recommended the installation of solar air-conditioning systems on a roof instead of on the walls for a high solar fraction. After comparing two solar airconditioning technologies, they found that the size of a trace collector solar air conditioner is acceptable. Their findings were supported by Otanicar et al. (2012).

The direct expansion wall-mounted air conditioner with a vapour compression cycle is a commonly used HVAC system. This system uses energy from fossil fuels and it can generate two to six times more thermal energy through absorption from renewable energy resources (Fu et al., 2012). However, aircooled air-conditioning systems are less energy efficient than water-cooled ones (Liang et al., 2011). The experimental test and dynamic simulation conducted by Liang et al. (2011) showed that electricity of approximately $6 \%$ of the daily total solar radiation can be obtained from a photovoltaic/thermal collector. The proposed system can save approximately $18 \%$ of the total energy consumption of the air conditioner. Guo and Shen (2009) presented a dynamic model for investigating the performance of a solar-driven ejector refrigeration plant for an office building. Their results demonstrated that the proposed system can conserve $75 \%$ more electricity than a traditional compressor-based air conditioner. La et al. (2011) combined a solar-driven, twostage rotary desiccant cooling plant with a vapour compression air-conditioning system and experimentally investigated the performance of the hybrid system. They found that the solar-driven desiccant cooling system can handle approximately $33 \%$ of the cooling load, which is equivalent to $34 \%$ reduction in

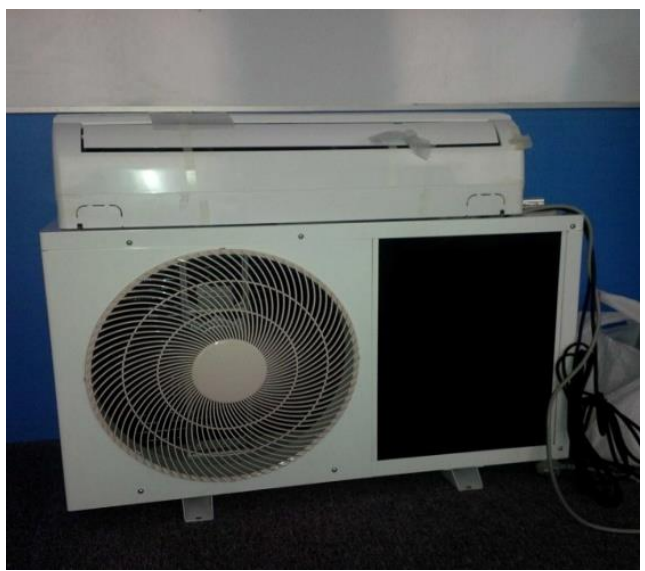

power consumption compared with a conventional vapour compression system. However, no study has reported the influence of installing solar vacuum collectors after the compressor on the energy performance of vapour compression air-conditioning systems. Such an approach simulates the dynamic behaviour of buildings and validates them with operational data collected from a real-world tested system.

\section{MATERIALS AND METHODS}

A split room air conditioner was used in this study. This type of room air conditioner is the most popular type in Malaysia, which accounts for $94 \%$ of room air conditioners sold in the market. To provide comfort, split room air conditioner uses a small refrigeration system connected with a copper pipe. The air conditioner hangs outside and inside the wall. The majority of room air conditioners sold in Malaysia use R22 as the working fluid. The cooling capacity of a room air conditioner ranges from $3 \mathrm{~kW}$ to $12 \mathrm{~kW}$.

Inverter-type and solar assisted airconditioning systems were compared. The inverter-type air conditioner controls the speed of the compressor motor to drive variable refrigerant flow in the system and regulate the temperature of the conditioned space. The solar-assisted air conditioners draw energy from solar rays and then convert the energy into electricity that can power the cooling system (Fig. 1). Given the time and budget constraints in running the test in the same building, the study was limited to two buildings with the same space volume in Kedah.

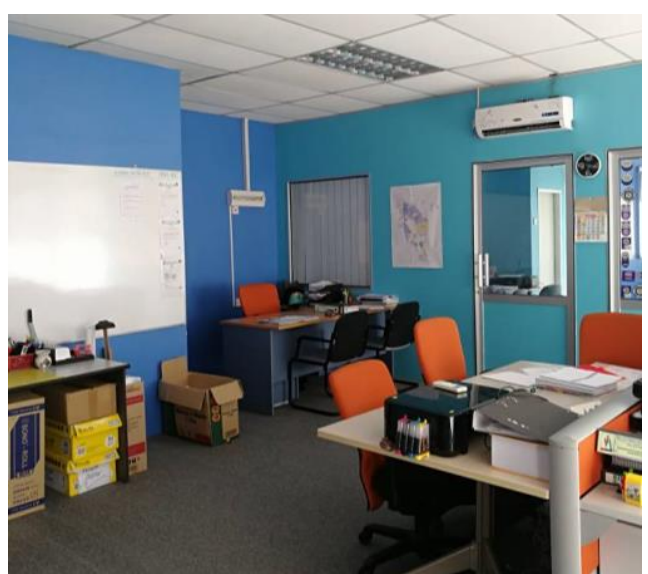

Fig. 1: Solar-assisted air-conditioning unit (left) and office building / case study (right) 
Measurement devices were installed at the site $30 \mathrm{~min}$ before actual measurement to ensure that the data recorded did not suffer from significant error. Data were recorded every 15 min during working hours from 9:00 a.m. to 5:00 p.m. for 3 days. Data were written in a data sheet every day before being transferred to a computer database. All data were recorded manually without the use of any scanner. The devices were calibrated and used under stable conditions (Table 1).

Table 1: Equipment for data collection

\begin{tabular}{|l|l|l|l|l|}
\hline Equipment & Multimeter & Lux meter & Anemometer & $\begin{array}{l}\text { Relative } \\
\text { Humidity Meter }\end{array}$ \\
\hline Description & $\begin{array}{l}\text { Kyoritsu Digital } \\
\text { Clamp Meter }\end{array}$ & $\begin{array}{l}\text { Extech Light } \\
\text { Meter }\end{array}$ & $\begin{array}{l}\text { Extech 45160 } \\
\text { Hygrometer }\end{array}$ \\
\hline Picture & &
\end{tabular}

\subsection{Solar Irradiance}

Irradiance refers to the power of solar radiation per unit area on a surface (Munaaim et al., 2016; Al-Obaidi et al., 2015). The global irradiance on a horizontal surface comprises direct irradiance and diffuse irradiance. Light intensity was measured using a lux meter, which generates values in "lux" unit. Light intensity values were converted from lux to $\mathrm{W} / \mathrm{m} 2$ by using the formula 1 lux $=0.0079$ $\mathrm{W} / \mathrm{m}^{2}$. Solar radiation affects many systems in a house and can vary considerably within the same town. On-site solar irradiance, which is a useful parameter of PV systems, can be expressed as

Irradiance $=$ lux reading $\times 0.0079 \mathrm{~W} / \mathrm{m} 2$

\subsection{Calculation of Performance}

Two factors, namely, cooling capacity and power consumption, were considered to evaluate the performance of the airconditioning system. Both factors depend on temperature and relative humidity.

Coefficient of performance (COP) was used to represent the performance of the room air conditioner. COP is the ratio of cooling capacity and the equivalent power input to the compressor:

$$
\mathrm{COP}=\frac{\text { Cooling Capacity }}{\text { Power Consumption }}
$$

which can be written in mathematical form as

$$
\mathrm{COP}=\frac{\mathrm{Q}_{\text {out }}}{\mathrm{W}_{\mathrm{in}}}
$$

\subsection{Cooling Capacity}

The cooling capacity of a refrigeration process is derived from the first law of thermodynamics, in which the kinetic and potential energies are neglected. However, the cooling capacity or cooling load can be calculated in different modes. In this study, the actual COP is derived by dividing cooling capacities from the air side. The cooling capacity of a room air conditioner can be calculated using the following equation:

$\mathrm{Q}_{\text {out }}=\mathrm{m}_{\text {air }} \mathrm{C}_{\mathrm{p} \text {-air }}\left(\mathrm{T}_{\text {air-out }}-\mathrm{T}_{\text {air-in }}\right)$.

\subsection{Power Input}

Power consumption is measured for the entire equipment, including the compressor, fans, and other accessories. The power consumption is calculated by

$$
\mathrm{W}_{\text {in }}=\mathrm{I} \times \mathrm{E} \times \mathrm{PF}
$$

Power factor (PF) is usually constant at 0.85 .

\section{RESULTS AND DISCUSSION}


According to the Malaysian Meteorological Department (MMD), the climate data of Kedah is similar to that of the general conditions in Malaysia. The temperature range outdoors is between $23{ }^{\circ} \mathrm{C}$ and $35{ }^{\circ} \mathrm{C}$. Table 2 shows the outdoor temperature readings that were taken at the time of the study. These readings were collected on three consecutive days to identify the appropriate climate conditions.
The voltage readings for both types of airconditioning systems were constant readings for all three days of the case study. The voltage readings of the solar-assisted air conditioner were $237 \mathrm{~V}$, whereas those of the inverter-type air conditioner were $236 \mathrm{~V}$.

Table 2: Readings of outdoor temperature

\begin{tabular}{|r|c|c|c|}
\hline \multirow{2}{*}{ Time } & \multicolumn{3}{|c|}{ Outdoor Temperature $\left({ }^{\circ} \mathbf{C}\right)$} \\
\cline { 2 - 4 } & $16-F e b-15$ & $17-F e b-15$ & $18-F e b-15$ \\
\hline 9:00 AM & 28.78 & 28.18 & 30.40 \\
\hline 10:00 AM & 31.05 & 29.48 & 29.15 \\
\hline 11:00 AM & 34.33 & 30.28 & 32.58 \\
\hline 12:00 PM & 34.65 & 32.70 & 33.15 \\
\hline 1:00 PM & 34.78 & 33.10 & 33.80 \\
\hline 2:00 PM & 32.68 & 33.43 & 34.23 \\
\hline 3:00 PM & 31.08 & 31.35 & 34.10 \\
\hline 4:00 PM & 33.10 & 31.45 & 32.60 \\
\hline 5:00 PM & 33.10 & 31.45 & 32.60 \\
\hline
\end{tabular}

\subsection{Results of the inverter-type air- conditioning system}

The observation data recorded on January 26, 2015 (Fig. 2) showed that solar irradiance increased until the afternoon and then dropped at 2:30 p.m. Solar irradiance increased from $500 \mathrm{~W} / \mathrm{m}^{2}$ to $800 \mathrm{~W} / \mathrm{m}^{2}$ and then decreased beginning at noon from $700 \mathrm{~W} / \mathrm{m}^{2}$ to $110 \mathrm{~W} / \mathrm{m}^{2}$. Power readings above $1000 \mathrm{~W}$ rate to $1100 \mathrm{~W}$ as a result of the climate began at 10:45 a.m. and lasted until 5:00 p.m. A power reading of $1100 \mathrm{~W}$ was recorded when the time was 12:45 p.m. Indoor temperature readings presented a uniform temperature of $24{ }^{\circ} \mathrm{C}$. However, the

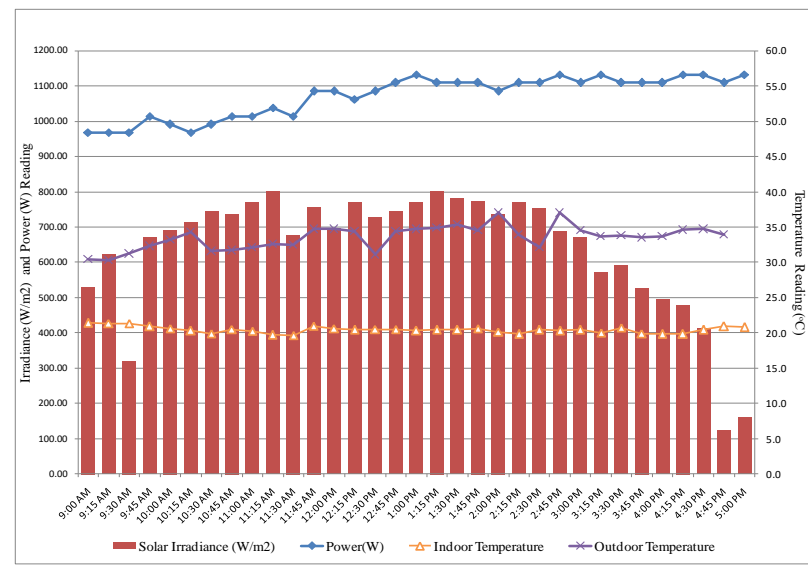

Fig. 2: Results of the inverter-type air conditioner on January 26, 2015 (first day) outdoor temperature was recorded in the range of $30{ }^{\circ} \mathrm{C}$ to $36{ }^{\circ} \mathrm{C}$.

The results on January 27, 2015 (Fig. 3) showed that the solar irradiance at 9:00 a.m. was higher than $200 \mathrm{~W} / \mathrm{m}^{2}$ and reached 815 $\mathrm{W} / \mathrm{m}^{2}$ at $12: 30$ p.m.. Solar irradiance around 5:00 p.m. decreased to $310 \mathrm{~W} / \mathrm{m}^{2}$. Solar irradiance readings indicated that it was a sunny day. Power readings from $1000 \mathrm{~W}$ and higher were recorded as early as 9:30 a.m. and exceeded $1100 \mathrm{~W}$ until late afternoon because outdoor temperatures were generally higher than $30{ }^{\circ} \mathrm{C}$ to $35{ }^{\circ} \mathrm{C}$. Indoor temperature fluctuated within the range of $19^{\circ} \mathrm{C}$ to $24^{\circ} \mathrm{C}$.

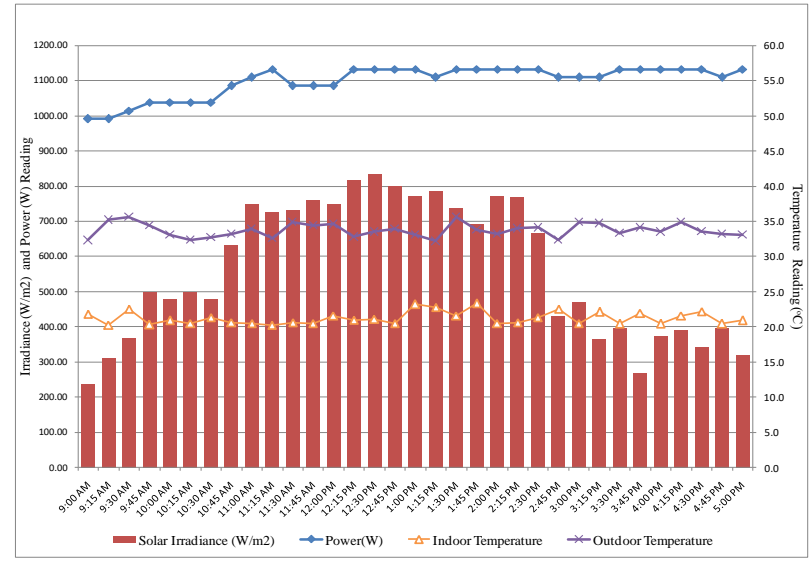

Fig. 3: Results of the inverter-type air conditioner on January 27, 2015 (second day) 
Solar irradiance readings on January 28, 2015 (Fig. 4) from 9:00 a.m. to 12:30 p.m. increased from $140 \mathrm{~W} / \mathrm{m}^{2}$ to $1000 \mathrm{~W} / \mathrm{m}^{2}$. Henceforth, the readings decreased slowly to $120 \mathrm{~W} / \mathrm{m}^{2}$. Solar irradiance readings on that day were higher than $1000 \mathrm{~W} / \mathrm{m}^{2}$. However, the prevailing sweltering conditions did not significantly affect the outdoor temperature, which was within the range of $31{ }^{\circ} \mathrm{C}$ to $36{ }^{\circ} \mathrm{C}$. Indoor temperature was within the range of 19 ${ }^{\circ} \mathrm{C}$ to $23{ }^{\circ} \mathrm{C}$, which is similar to the temperature readings in the two previous days.

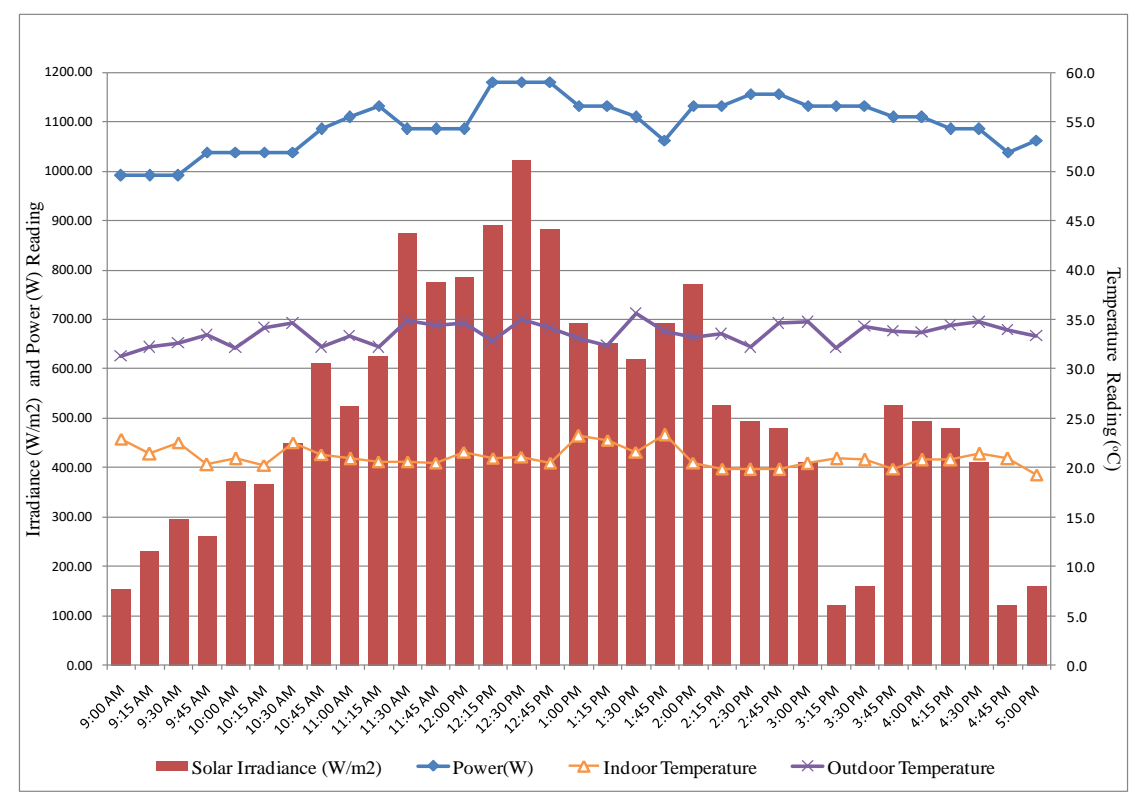

Fig. 4: Results of the inverter-type air conditioner on January 28, 2015 (third day)

\subsection{Results of Solar-Assisted Air- Conditioning System}

Solar irradiance results on February 16, 2015 (Fig. 5) shows that solar irradiance begin to increase at 9:00 a.m., when the reading was $300 \mathrm{~W} / \mathrm{m}^{2}$, up to $1: 30$ p.m., when the reading was approximately $900 \mathrm{~W} / \mathrm{m}^{2}$. Solar irradiance after 1:30 p.m. decreased from $850 \mathrm{~W} / \mathrm{m}^{2}$ to
$800 \mathrm{~W} / \mathrm{m}^{2}$ and then sharply declined to lower than $200 \mathrm{~W} / \mathrm{m}^{2}$ at 3:00 p.m. This drastic decrease in solar irradiance below $200 \mathrm{~W} / \mathrm{m}^{2}$ influenced the power recorded at 3:00 p.m. $(1000 \mathrm{~W})$. Outdoor temperature readings fluctuated between $30{ }^{\circ} \mathrm{C}$ and $35^{\circ} \mathrm{C}$, and the indoor temperatures ranged from $25{ }^{\circ} \mathrm{C}$ to 31 ${ }^{\circ} \mathrm{C}$.

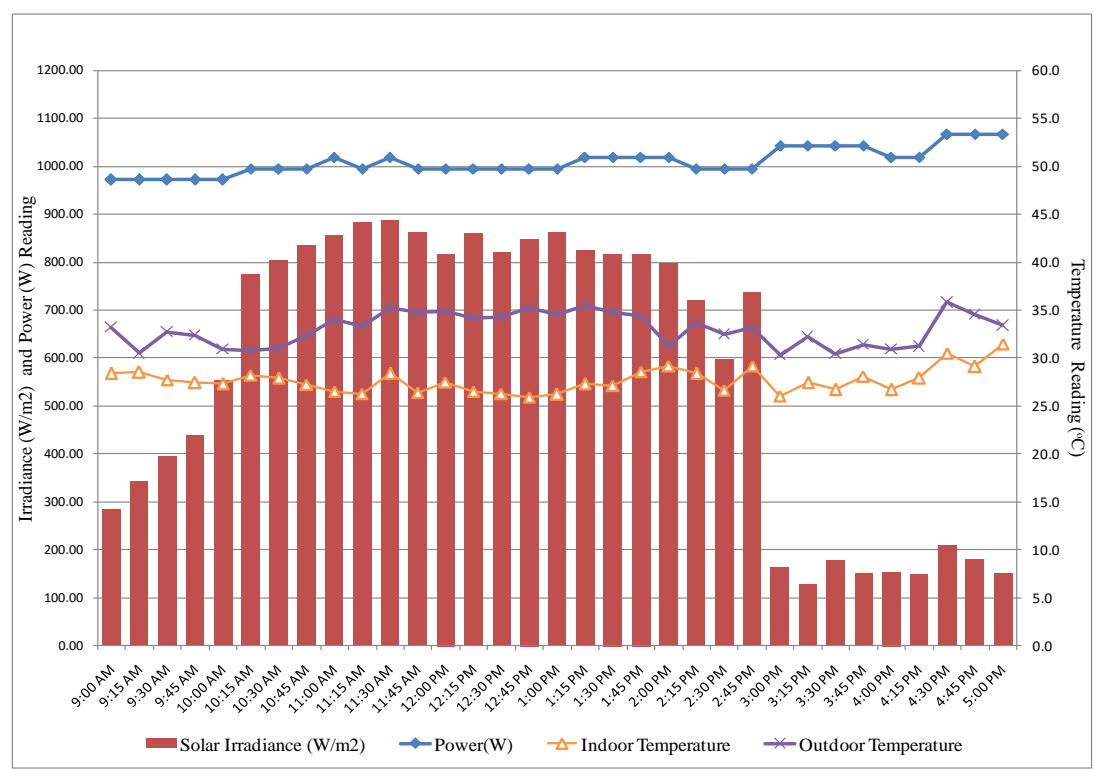

Fig. 5: Results of the solar-assisted air conditioner on February 16, 2015 (first day) 
The data recorded on February 17, 2015 (Fig. 6) presented a slight improvement in the level of irradiance at 9:00 a.m. However, after 10:30 am, the uniform pattern of solar irradiances showed cloud cover interruptions, which prevented direct sunlight from hitting the earth's surface. Consequently, the power reached $1000 \mathrm{~W}$ at 11:15 a.m. until the evening. These results showed that solar irradiance affects solar assisted air-conditioning systems. Outdoor and indoor temperatures on the heat balance of the building were below the range of $30{ }^{\circ} \mathrm{C}$ to $35^{\circ} \mathrm{C}$ and $24{ }^{\circ} \mathrm{C}$ to $27^{\circ} \mathrm{C}$.

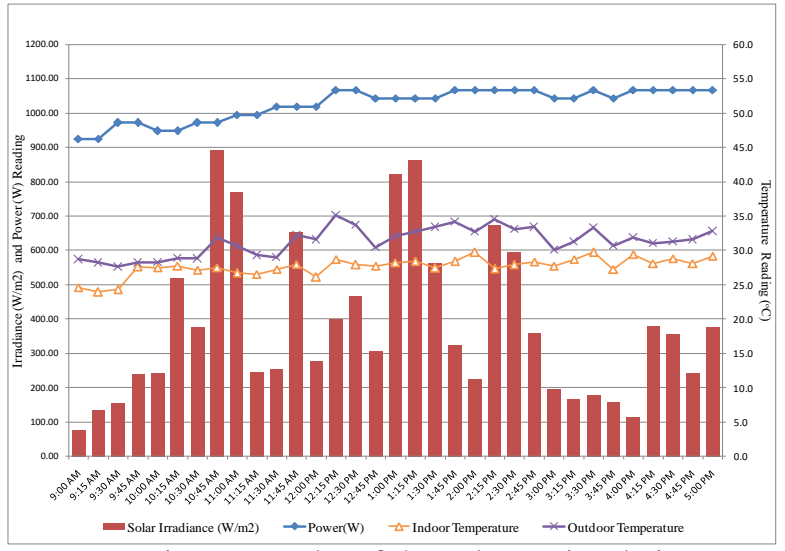

Fig. 6: Results of the solar-assisted air conditioner on February 17, 2015 (second day)

\subsection{Differences in solar irradiance}

As previously mentioned, irradiance readings were derived by measuring the solar radiation in the area with an illuminancemeasuring device (lux meter) and then converting it to solar irradiance. The results of solar irradiance are shown in Fig. 8, which demonstrates good climate in Sungai Petani, Kedah, during the time of study.
On February 18, 2015 (Fig. 7), the solar irradiance increased from 9:00 a.m. until 12:30 p.m.. Henceforth, solar irradiance readings fluctuated within the range of $630 \mathrm{~W} / \mathrm{m}^{2}$ to 370 $\mathrm{W} / \mathrm{m}^{2}$. Solar irradiance at $4: 45 \mathrm{p} . \mathrm{m}$. reached the minimum value of $100 \mathrm{~W} / \mathrm{m}^{2}$. Solar irradiance caused the power readings to increase from $1000 \mathrm{~W}$ at 11:00 a.m. and then decreased at around 12:45 p.m. Accordingly, the outdoor temperature around that time also decreased to nearly $30{ }^{\circ} \mathrm{C}$; however, climate conditions in the area was generally consistent. Optimal indoor air temperature was $24^{\circ} \mathrm{C}$.

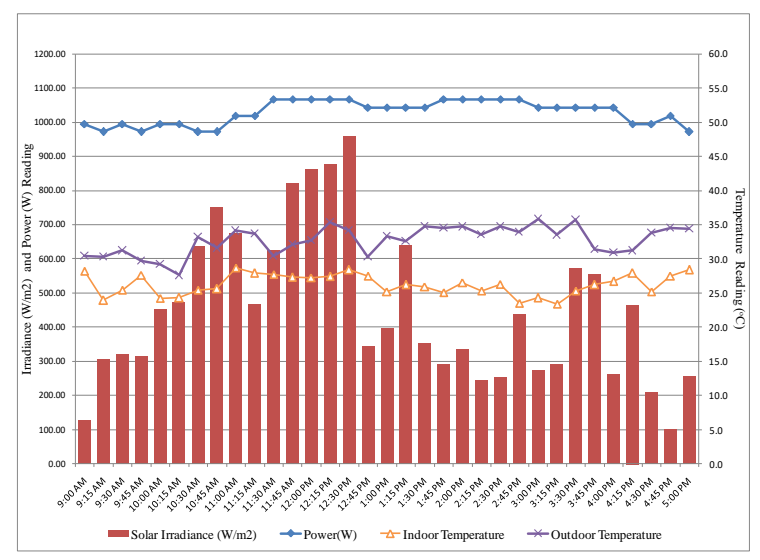

Fig. 7: Results of the solar-assisted air conditioner on February 18, 2015 (third dav)

Cover cloud interruptions did not occur on February 16, 2015. As a result, the transmission of radiation on the PV panels, which were installed directly on the outdoor airconditioning unit, was enhanced. Solar irradiance readings on two consecutive days were consistent. The climate in Malaysia is hot throughout the year, and the climate in Sungai Petani remarkably impacts the use of solarassisted air-conditioning.

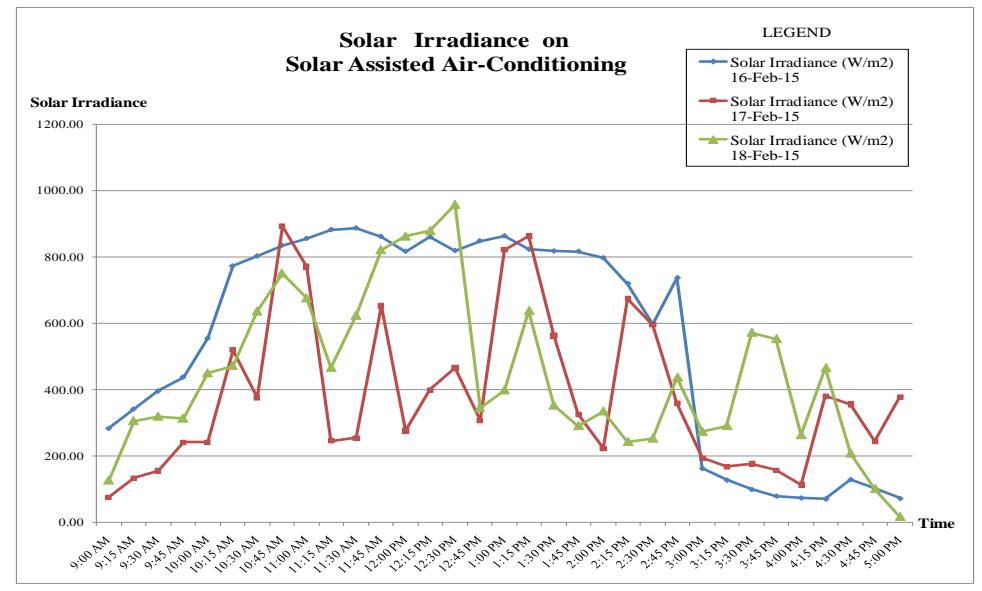

Fig. 8: Differences in solar irradiance across measurement days 
3.4 Temperature effects on the current of solar-assisted air-conditioning

The electricity generated by the PV panels is influenced by the temperature during the airconditioning operation and is therefore affected by the outdoor air temperature and sunlight intensity. Although the intensity of the sunlight is the most important factor in the efficiency of the power output of the solar panel, temperature and other environmental factors can reduce the efficiency and the energy output of the solar panel. Temperature between $23{ }^{\circ} \mathrm{C}$ and $34{ }^{\circ} \mathrm{C}$ is favourable to solar assisted air-conditioning performance even if the solar irradiance range is uneven. The power range of the solar assisted air-conditioning was between $945 \mathrm{~W}$ and 1065 $\mathrm{W}$ in $15 \mathrm{~min}$, as shown in Fig. 8. These results indicate that these temperature and power range are appropriate for saving energy, as shown in Fig. 9. Solar irradiance and outdoor air temperature are important factors in ensuring the performance and the applicability of the solar assisted air-conditioning system. In fact, the PV panels installed on the outdoor unit have a certain degree of acceptance. If the temperature is too high, then electric power will be provided directly without the help of solar energy.

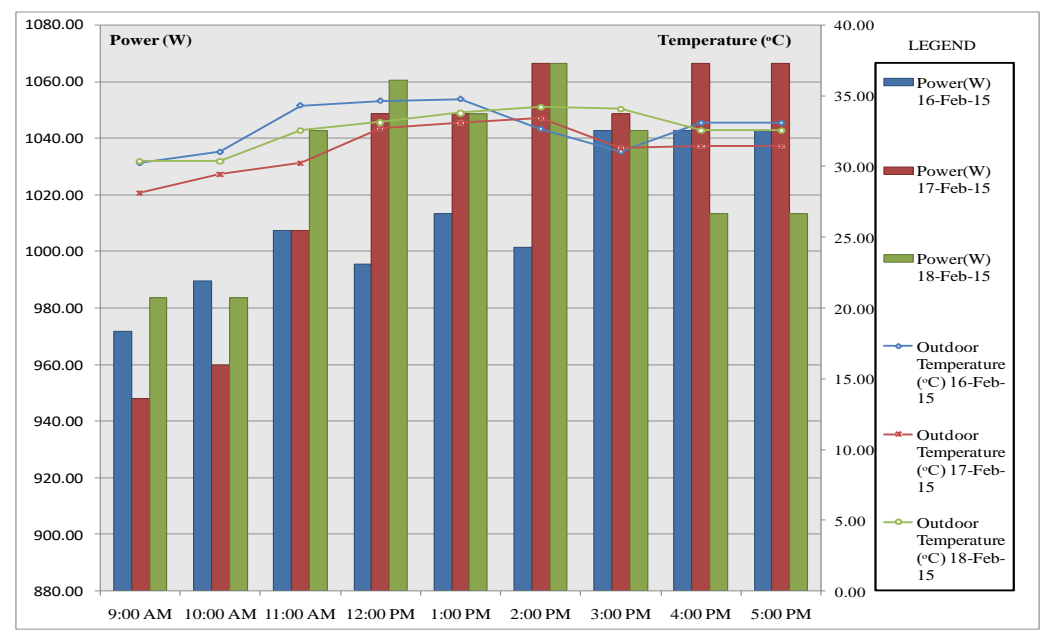

Fig. 9: Results of temperature and power for the solar-assisted air-conditioning system

\subsection{Coefficient of performance of the solar- assisted air-conditioning system}

The air-conditioning unit should present applicability and the capacity to bear the influence of the environment. The average coefficients of performance achieved by the solar-assisted air-conditioning system ranged from 3.00 to 4.45 (Table 3). This range allows for the optimal electric energy consumption without wastage. Therefore, the solar-assisted air-conditioning system is environmentally friendly. Moreover, an air-conditioning unit with a high coefficient of performance can promote the efficient use of electric energy

Table 3: Average coefficients of performance of the solar-assisted air-conditioning system

\begin{tabular}{|l|c|c|c|}
\hline \multirow{2}{*}{ Time } & \multicolumn{3}{|c|}{ Coefficient of Performance } \\
\cline { 2 - 4 } & $16-$ Feb-15 & $17-$ Feb-15 & 18 -Feb-15 \\
\hline 9:00 AM & 0.31 & 0.43 & 1.10 \\
\hline 10:00 AM & 0.45 & 0.27 & 0.66 \\
\hline 11:00 AM & 0.96 & 0.41 & 0.56 \\
\hline 12:00 PM & 1.06 & 0.64 & 0.64 \\
\hline 1:00 PM & 0.97 & 0.62 & 1.68 \\
\hline 2:00 PM & 0.57 & 0.63 & 1.72 \\
\hline 3:00 PM & 0.50 & 0.38 & 1.50 \\
\hline 4:00 PM & 0.57 & 0.31 & 0.52 \\
\hline 5:00 PM & 0.57 & 0.31 & 0.52 \\
\hline Coefficient of Performance & 2.98 & 2.00 & 4.45 \\
\hline
\end{tabular}


3.6 Comparison of the power usage values of the solar-assisted and inverter-type airconditioning systems

Fig. 10 shows the average power usage values of both types of air-conditioning systems. The electric power consumption in the figure is applicable to the inverter-type air conditioner.
Inverter technology indirectly optimizes electricity consumption. The data in Fig. 10 show that the solar assisted air-conditioning system is comparable with the inverter-type system. Furthermore, the solar assisted airconditioning can leverage the advantages of the additional components of the PV panel.

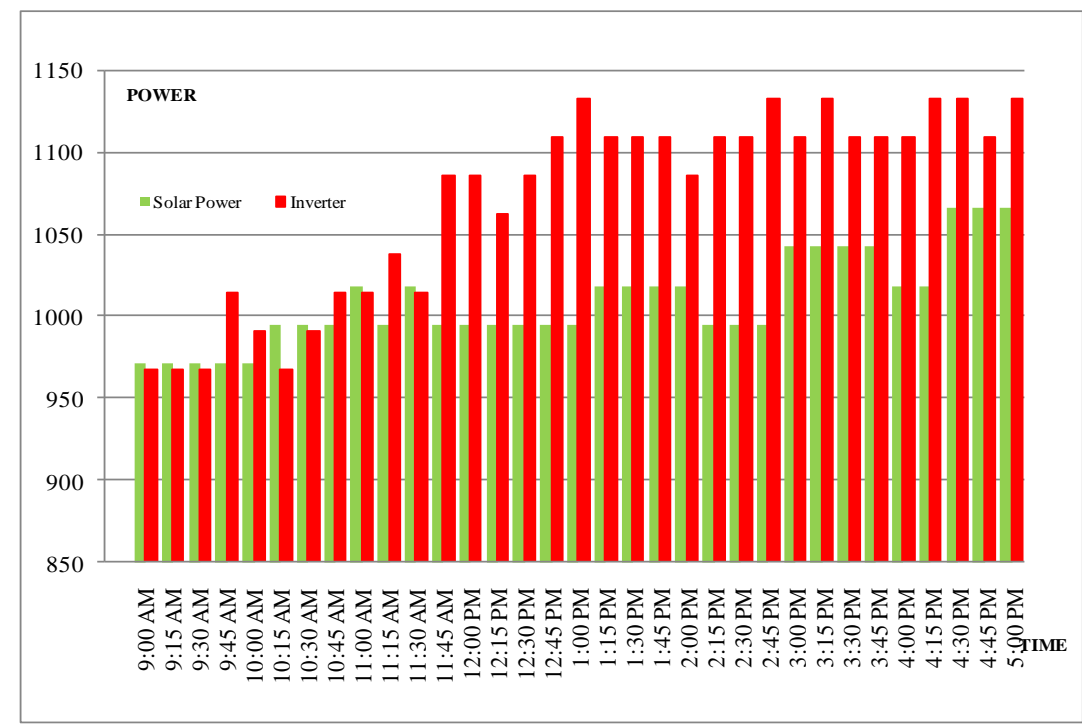

Fig. 10: Comparison of the power usage values between solar assisted with inverter air-conditioning

A comparison between solar-assisted and inverter-type air-conditioning systems showed the efficiency of diesel fuel in terms of electric power consumption. The inverter-type airconditioning system is equally good in maintaining the level of efficiency amid changing weather conditions. Solar irradiance functions as a sourcing agent that can help solar-assisted air-conditioning systems collect and combine solar energy with provided electricity. Fig. 11 shows that both types of airconditioning units show minimal difference in terms of power consumption, but both can achieve power consumption reduction.

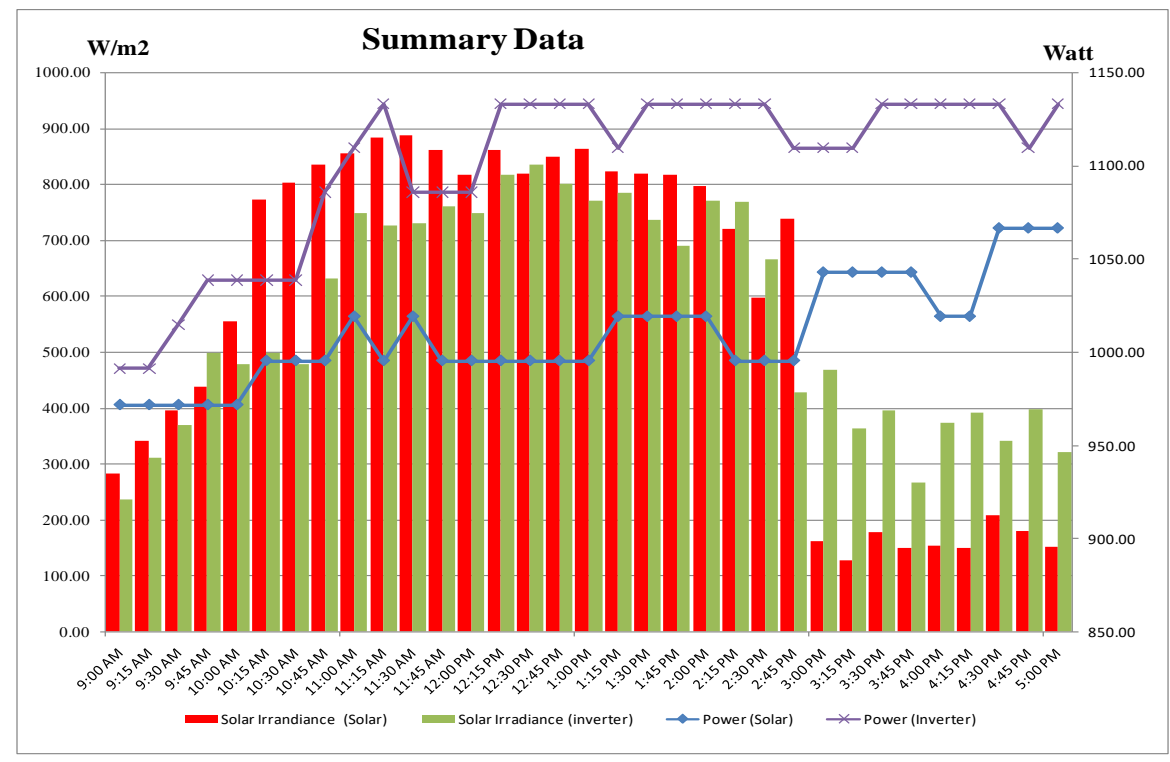

Fig. 11: Summary of the power used by the solar-assisted and inverter-type air-conditioning unit 


\section{SUMMARY}

In this study, the potential of $1.5 \mathrm{HP}$ solarassisted air-conditioning unit was evaluated based on real data (empirical) collected in a Malaysian environment. The solar airconditioning unit has a higher coefficient of performance than that of the inverter-type one. Furthermore, the former presents an environmentally friendly alternative to meet the thrusts of the Ministry of Energy, Green Technology and Water of reducing electricity rates and promoting the use of renewable energy. By contrast, the inverter-type system still fails to reach the ideal levels of use, and its electric power consumption is higher than that of the solar-assisted air-conditioning system.

\section{REFERENCES}

Al-Abidi, A. A., Mat, S. B., Sopian, K., Sulaiman, M. Y., Lim, C. H., \& Th, A. (2012). Review of thermal energy storage for air conditioning systems. Renewable and Sustainable Energy Reviews, 16(8), 58025819.

Al-Obaidi, K. M., Ismail, M. A., \& Abdul Rahman, A. M. (2015). Assessing the allowable daylight illuminance from skylights in single-storey buildings in Malaysia: a review. International Journal of Sustainable Building Technology and Urban Development, 6(4), 236-248.

Al-Obaidi, K. M., Munaaim, M. A. C., Ismail, M. A., \& Rahman, A. M. A. (2017). Designing an integrated daylighting system for deep-plan spaces in Malaysian low-rise buildings. Solar Energy, 149, 85-101.

Aminuddin, A. M. R., \& Rao, S. P. (2008). Sustainable air-conditioning for the tropical buildings. Journal of Design and Built Environment, 4(1).

Balaras, C. A., Grossman, G., Henning, H. M., Ferreira, C. A. I., Podesser, E., Wang, L., \& Wiemken, E. (2007). Solar air conditioning in Europe-an overview. Renewable and sustainable energy reviews, 11(2), 299-314.

Fong, K. F., Chow, T. T., Lee, C. K., Lin, Z., \& Chan, L. S. (2010). Comparative study of different solar cooling systems for buildings in subtropical city. Solar Energy, 84(2), 227-244.

Fu, H. D., Pei, G., Ji, J., Long, H., Zhang, T., \& Chow, T. T. (2012). Experimental study of a photovoltaic solar-assisted heat-pump/heatpipe system. Applied Thermal Engineering, 40, 343-350.

Guo, J., \& Shen, H. G. (2009). Modeling solardriven ejector refrigeration system offering air conditioning for office buildings. Energy and Buildings, 41(2), 175-181.

Gupta, Y. (2011). Research and development of a small-scale adsorption cooling system. Arizona State University.

La, D., Dai, Y., Li, Y., Ge, T., \& Wang, R. (2011). Case study and theoretical analysis of a solar driven two-stage rotary desiccant cooling system assisted by vapor compression air-conditioning. Solar energy, 85(11), 2997-3009.

Liang, C. H., Zhang, X. S., Li, X. W., \& Zhu, X. (2011). Study on the performance of a solar assisted air source heat pump system for building heating. Energy and Buildings, 43(9), 2188-2196.

Munaaim, M. A. C., Al-Obaidi, K. M., Ismail, M. R., \& Rahman, A. M. A. (2014). A review study on the application of the fibre optic daylighting system in Malaysian buildings. International Journal of Sustainable Building Technology and Urban Development, 5(3), 146-158.

Munaaim, M. A. C., Al-Obaidi, K. M., Ismail, M. R., \& Abdul Rahman, A. M. (2016). Potential of fibre optic daylighting systems in tropical Malaysia. Indoor and Built Environment, 25(3), 466-480.

Otanicar, T., Taylor, R. A., \& Phelan, P. E. (2012). Prospects for solar cooling-An economic and environmental assessment. Solar Energy, 86(5), 12871299.

Saidur, R., Masjuki, H. H., \& Jamaluddin, M. Y. (2007). An application of energy and exergy analysis in residential sector of Malaysia. Energy Policy, 35(2), 1050-1063.

Sulaiman, R. (2005). A Review of Solar Energy and the Built Environment. Journal of Design and Built Environment, 1(1). 